DEMOGRAPHIC RESEARCH

VOLUME 36, ARTICLE 58, PAGES 1785-1812 PUBLISHED 8 JUNE 2017

http://www.demographic-research.org/Volumes/Vol36/58/

DOI: 10.4054/DemRes.2017.36.58

Research Article

\title{
The socioeconomic determinants of repartnering after divorce or separation in Belgium
}

\section{Inge Pasteels}

\section{Dimitri Mortelmans}

This publication is part of the Special Collection on "Separation, Divorce, Repartnering, and Remarriage around the World," organized by Guest Editors Benoît Laplante and Andrew Cherlin.

\section{(C) 2017 Inge Pasteels \& Dimitri Mortelmans.}

This open-access work is published under the terms of the Creative Commons Attribution NonCommercial License 2.0 Germany, which permits use, reproduction \& distribution in any medium for non-commercial purposes, provided the original author(s) and source are given credit. See http:// creativecommons.org/licenses/by-nc/2.0/de/ 


\section{Contents}

1 Introduction $\quad 1786$

$\begin{array}{lll}2 & \text { Theory and hypotheses } & 1787\end{array}$

3 Methods 1793

$\begin{array}{lll}3.1 & \text { Data } & 1793\end{array}$

$\begin{array}{lll}3.2 & \text { Measurements } & 1796\end{array}$

$\begin{array}{lll}3.3 & \text { Analytical strategy } & 1798\end{array}$

$4 \quad$ Results 1798

5 Discussion 1804

6 Acknowledgements 1806

$\begin{array}{ll}\text { References } & 1807\end{array}$ 


\title{
The socioeconomic determinants of repartnering after divorce or separation in Belgium
}

\author{
Inge Pasteels ${ }^{1}$ \\ Dimitri Mortelmans ${ }^{2}$
}

\begin{abstract}

\section{BACKGROUND}

The increasing prevalence of higher-order unions is one of the major changes in family life in recent decades.
\end{abstract}

\section{OBJECTIVE}

By using register data, we aim to give a unique view on how income components amount and composition - influence the likelihood of repartnering after divorce or separation in Belgium.

\section{METHODS}

We analyse a sample of 46,648 broken marriages and 67,053 separated cohabitations from the Belgian Data Warehouse Labour Market and Social Protection database, using discrete-time event history models.

\section{RESULTS}

The chances of men repartnering increase in higher income quintiles. Women in lower income quintiles are more likely to repartner, while women in higher income groups are less likely to repartner. These patterns have been found to hold regardless of the type of previous union. Furthermore, divorcees are more likely to repartner than former cohabiters are. The type of previous relationship hardly influences the impact of the amount of income on repartnering dynamics. As for the composition of income, being divorced decreases repartnering chances in cases of irregular labour, irrespective of gender. Women who are in work are more likely to repartner if they are divorced rather than separated, while men receiving unemployment benefits and integration income are more likely to repartner if they are divorced.

\section{CONCLUSIONS}

Repartnering is evolving to a two-tier system, with a wide discrepancy between lowest

\footnotetext{
${ }^{1}$ Social Work Research, PXL University College, Hasselt, Belgium, and Centre for Longitudinal and Life Course Studies (CLLS), Universiteit Antwerpen, Belgium. E-Mail: inge.pasteels@pxl.be.

${ }^{2}$ Centre for Longitudinal and Life Course Studies (CLLS), Universiteit Antwerpen, Belgium.
} 
and highest income groups. Type of previous relationship makes hardly any difference to the impact of the amount of income on repartnering dynamics, but partially drives the impact of the composition of income.

\section{Introduction}

As a result of increasing divorce and separation rates among couples in recent decades, repartnering has become increasingly important in understanding the dynamics of partnership formation. Relevant research initially focused on the dynamics of first marriage and general first-union formation (e.g., Becker 1981; Oppenheimer 1988; Bumpass, Sweet, and Castro-Martin 1990; Heuveline and Timberlake 2004; Dykstra and Poortman 2009). However, in recent decades research about repartnering has emerged which also takes into account unmarried cohabitation (e.g., Coleman, Ganong, and Fine 2000; de Graaf and Kalmijn 2003; Beaujouan 2012; Ivanova, Kalmijn, and Uunk 2013; Pasteels and Mortelmans 2015; Vanassche, Corijn, and Matthijs 2015).

Economic resources have been explored as a determinant of repartnering, because divorce and separation have a substantial negative influence on economic well-being (Smock 1994; Jarvis and Jenkins 1999; Poortman 2000; Amato 2010). The economic consequences of divorce tend to be harsher for women than for men, because of gender differences in labour market participation, earnings, household organization, and childcare responsibilities. Accordingly, repartnering is an important strategy to cope with financial stress after separation or divorce (Smock 1994; Sweeney 1997; Schmiege, Richards, and Zvonkovic 2001; Ozawa and Yoon 2002; Jansen, Mortelmans, and Snoeckx 2009; Dewilde and Uunk 2008).

Inspired by Elder (1998), we consider repartnering as an event that can occur at any time in the life course, whereby individual choices may vary depending on individual trajectories, which are the cumulative experiences of an individual over their lifetime (Elder, Johnson, and Crosnoe 2003). Divorce after marriage and separation after unmarried cohabitation can respectively be seen as different outcomes of individual trajectories with varying choices and corresponding cumulative experiences, whereby repartnering can be a next phase. Different experiences in each of these trajectories can take place in various domains: for example, family life with having children or remaining childless, labour market participation.

It is suggested in relevant literature that besides family indicators, such as having children, various socioeconomic variables, such as employment and income, can also be important determinants of repartnering behaviour, but it cannot always be explained why mixed effects are found. We attempt to fill this gap by analysing whether 
economic resources influence the likelihood of repartnering differently according to the status of the previous union. After all, the most convincing argument for examining the repartnering patterns of divorcees and former cohabiters separately stems from the important differences in the legal context in which the divorce or separation process occurs, whereby partner alimony guaranteeing mutual responsibility in obtaining economic resources after the break-up of the relationship is regulated only in the context of divorce.

With this study, we contribute to existing literature about socioeconomic determinants on repartnering in two ways. First, we compare the economic determinants of repartnering for divorcees with those for former cohabiters. Second, we elaborate on the concept of economic resources by considering two dimensions of income in a time-varying way: both amount and composition. This elaboration of income as indicator of economic resources is in line with the "needs," "attractiveness," and "opportunity" theory of de Graaf and Kalmijn (2003), in which different reasons for repartnering are distinguished. By considering the composition of income for divorced or separated men and women, we try to clarify repartnering dynamics in this theoretical perspective.

The current analysis therefore greatly improves on previous measurements of earnings and introduces the idea of a life course perspective by considering the type of previous relationship, while studying economic resources as influential factors in repartnering. Since the amount and source of economic resources are often genderinfluenced and the socioeconomic consequences of relationship dissolution are sharper for women than for men, we run separate analyses for both sexes.

It is worthwhile analysing Belgian data for this study, given the country's position as a front-runner in European divorce statistics, with crude divorce rates between 2.8 and 3.3 from 2002 to 2008 . The crude divorce rate has only recently decreased (to 2.3 in 2012) (Eurostat 2015). For two-thirds of all marriages entered into in 2013, at least one of the spouses had previously been married (ADSEI 2014). Moreover, 10\% of spouses starting a first marriage after 1995 had previously cohabited with someone else without marrying (Pasteels, Lodewijckx, and Mortelmans 2015). Some 36\% of men and $40 \%$ of women who divorced between 2001 and 2005 started a new cohabitation within two years (Pasteels and Mortelmans 2013). 


\section{Theory and hypotheses}

Repartnering through a life course perspective: Divorce or separation and subsequent repartnering are events that occur during the life course as parts of an individual trajectory. Life course theory emphasizes the importance of understanding and incorporating these individual trajectories in order to explain the occurrence of life course events (Elder 1998; Elder, Johnson, and Crosnoe 2003). When studying entire life course trajectories or particular events in the life course, two perspectives are often considered. The first refers to family life, with partnership and parenthood as two main components. The second relates to socioeconomic indicators, such as education, labour force participation, and earnings. Most literature dealing with repartnering issues incorporates at least one of these two perspectives. We combine both, by focusing on income and the type of previous relationship as the main determinants of repartnering. First, we shed light on the socioeconomic determinants of repartnering. Second, we consider cohabitation as opposed to marriage as the previous type of relationship in which socioeconomic determinants can occur.

Socioeconomic determinants: Becker's (1981) "gains to trade" model is a wellknown theory predicting the relationship between socioeconomic prospects and entry into first marriage. It posits that good socioeconomic prospects will increase the likelihood of marriage for men, but decrease the likelihood for women. The underlying idea is that single men and women are considered as trading partners who want to maximize the gains from marriage. According to Becker, these gains are greatest when men and women specialize in the labour market and the home respectively.

In contrast, Oppenheimer's (1988) "career entry" theory suggests that changes in the labour market positions of both women and men have altered the nature of the marital bargain, rather than making marriage unnecessary or undesirable. In line with Easterlin's (1978) "relative income" hypothesis, which highlights the economic feasibility of marriage as the main determinant of marriage formation, Oppenheimer argues that the characteristics considered important in a spouse have become more symmetrical for men and women. Consequently, women are evaluated more on the basis of their own income and labour market prospects than on traditional characteristics, such as being a good housewife or a good mother for children later in life. Moreover, with dual-earner families as the norm, high-resource women have presumably become more attractive partners (Sweeney 2002; Shafer and Spencer 2013). Therefore, good socioeconomic prospects for both men and women will increase entry into marriage.

Sweeney (2002) found that men and women increasingly resemble one another with regard to the relationship between economic prospects and first marriage. The economic context of contemporary marriage is dominated more by concerns about the 
affordability of marriage than by efforts to maximize the benefits of specialization. She concludes that Becker's specialization and trading model of marriage may be outdated, as perceptions of economic need are no longer applicable to the current marriage regime.

These economically inspired theories, formulated to explain patterns of firstmarriage or first-union formation, can easily be extended to include the formation patterns of higher-order unions. Some recent studies have also explored, among other things, the socioeconomic determinants of repartnering. Employment reduces women's overall repartnering rate (remarriage as well as cohabitation) and men's entry into cohabitation (Wu and Schimmele 2005). Another study shows that the effect of occupational status is sensitive to a woman's age at separation. Depending on the age at which divorce occurred, mixed results are found with regard to the socioeconomic determinants of repartnering. The effect of occupational status is negative for women separating at younger ages, yet positive for women separating at older ages. Socioeconomic prospects are not found to be related to the remarriage of men (Sweeney 2002). Support for the economic-needs hypothesis of repartnering is found in the comparative research by Dewilde and Uunk (2008). They note that a decline in income after divorce increases the likelihood of remarriage for women.

The theoretical framework of repartnering was broadened by de Graaf and Kalmijn (2003), who suggest that "need," "attractiveness," and "opportunity" are three main reasons why people enter into cohabiting unions. Using these concepts, it might be expected that the more economically independent a woman is, the less need she has to repartner. With regard to men, their attractiveness increases in line with their income level and accordingly their likelihood of repartnering also increases (Mott and Moore 1983; Sweeney 1997).

However, research does not consistently support the economic-needs hypothesis in explaining the repartnering mechanism, either for men or for women. A greater degree of economic dependency makes women less attractive as possible new partners. Research by de Graaf and Kalmijn (2003) shows that women who contribute little to family income during marriage or who have more trouble making ends meet are not more likely to repartner than other women, as would be expected from the economicneeds hypothesis. Furthermore, women's participation in the labour market after divorce does not have a significant effect on repartnering rates. The researchers found that the effect of labour market participation is driven by the social interpretation of work and not by the financial interpretation, meaning that work provides a setting that favours meeting potential new partners. The same conclusion was drawn with regard to the association between men's labour force participation and their repartnering chances. For men also, being in work does not increase repartnering outside the work context, suggesting that greater attractiveness on the part of working men is not the reason that 
they repartner more often; it is instead the opportunity to meet potential candidates at work.

Even for women living on social welfare, the economic-needs hypothesis is not supported by recent empirical studies. Hughes (2000), as well as de Graaf and Kalmijn (2003), found that women on welfare with lower resource levels, and thus greater levels of economic need, are less likely to repartner. De Graaf and Kalmijn conclude that working women have the highest repartnering rate and women on welfare the lowest, while women with other income sources, such as sickness or unemployment benefits, are in between. The negative effect of welfare relates only to the propensity to marry and does not affect cohabitation, because payments are portable to a new relationship only when it does not involve marriage.

Using empirical results from relevant literature, we test the following hypotheses about socioeconomic determinants in the current study:

(i) Women and men with lower incomes are more likely to repartner because of greater economic need.

(ii) Women and men with lower incomes are less likely to repartner because of seeming less attractive.

(iii) Having an income from work rather than receiving social welfare increases the likelihood of repartnering because it makes both men and women seem more attractive, while being at work offers opportunities to meet.

Family life - cohabitation versus marriage: Declining marriage rates and increasing cohabitation rates are crucial elements of family change in recent decades, and the meaning of marriage has altered over time (Cherlin 2004a, 2004b; Amato et al. 2007). Love, sexuality, and childbearing are no longer inextricably entwined with marriage (Zwaan 1993). Unmarried cohabitation initially came about as an alternative to remaining single (Rindfuss and van den Heuvel 1990). Once marriage was no longer the only context for childbearing and unmarried cohabiting couples increasingly had children (Sobotka and Toulemon 2008) - because of changing norms and values that broke the traditional link between marriage and childbearing (Billari 2001) - unmarried cohabitation became an alternative to marriage (Manning 1993; Smock 2000; Raley 2001; Kiernan 2004). Several classifications of unmarried cohabitation offer an insight into how this type of relationship has evolved over time, from a prelude to marriage to an alternative (Heuveline and Timberlake 2004; Perrelli-Harris et al. 2009; Hiekel, Liefbroer, and Poortman 2012). The speed of this evolution differs between European 
regions. Belgium is in a middle group in which unmarried cohabitation has become more prevalent in recent decades (Kiernan 2004; Pasteels, Corijn, and Mortelmans 2012).

The type of previous relationship already appears important in order to explain the repartnering mechanism. People who have previously been married have a lower likelihood of repartnering than those who have only cohabited (Poortman 2007; Wu and Schimmele 2005). Skew and colleagues (2009) added more detail to these findings. The previous relationship status does matter, but it is not the difference between those who had previously been married or had cohabited that is important; the differences in repartnering behaviour are between those who had previously been married preceded by cohabitation compared with everyone else. Because we do not include marriages preceded by cohabitation in our analytical sample, we follow the authors mentioned above and only hypothesize that:

(iv) People who have never married are more likely to repartner than divorcees are.

The legal context of unmarried cohabitation versus marriage can give insight into repartnering chances. Unmarried cohabitation cannot currently be considered a valuable alternative to marriage because of differences in formal support for the two types of relationships. Therefore, despite a decline in first-marriage rates, rising rates of cohabitation, and an increasing variety in relationship formation, it seems quite incredible to suggest that marriage would ever disappear (Seltzer 2004). In Belgium, as well as in other countries, unmarried cohabiters have been granted a number of legal rights similar to those of married couples, but important differences continue to exist (Lyssens-Danneboom, Eggermont, and Mortelmans 2013). The notion of cohabitation was introduced into the Belgian legal system in 1998 and legislation came into force in January 2000. Although the legal definition of cohabitation has been evolving towards that of marriage with regard to numerous aspects of family life - such as study allowances, parental leave, and adoption - the protection of partners in the case of separation still differs. When married couples divorce, the court may order one spouse to pay alimony to their ex-partner. In the case of cohabitation, this protection is not provided for the economically weaker party in the separation. Moreover, the legislation starts off from certain assumptions concerning the intentions, practices, and expectations of the couples concerned and one of these assumptions is "an emphasis on autonomy rather than on solidarity: separation of property." Solidarity is limited to the duration of the relationship, and the obligation to contribute proportionally ends under law when the legally recognized cohabitation is officially terminated. The protection of 
ex-partners by mutual solidarity after separation in the case of an unmarried cohabitation that has never been legally recognized is completely nonexistent.

(v) The economic-needs hypothesis will be less applicable to women in the context of dissolved marriages compared with separated cohabitations because the legal context of divorce after marriage provides the opportunity to obtain alimony from an ex-husband if an ex-wife is the economically weaker party after divorce.

A second argument for examining the likelihood of repartnering for divorcees and former cohabiters separately is that there are norms and values that characterize each type of partnership. If we consider marriage as a union in accordance with more traditional norms and values - compared with unmarried cohabitation - then differences between unmarried cohabitation and marriage could also exist regarding the extent to which Becker's (1981) specialization theory has to be considered outdated. Gender roles have changed, with an increasing contribution by men to unpaid work and increasing participation in the labour force by women (Blossfeld and Drobnic 2001). However, have they changed in the same way in all types of partnerships, or are marriages still more traditionally slanted, with a gender-based division of labour? Referring to the idea of different choices and cumulative experiences within the life course perspective, one could assume that divorce would occur more in a context where the male-breadwinner model is prevalent, while the dual-earners model is more common in unmarried cohabitations. If so, economic needs after separation or divorce might also differ accordingly. By combining literature on previous partnerships and their legal context and underlying arguments based on norms and values, we hypothesize:

(vi) Opportunity theory, which states that participating in the labour force provides opportunities to meet and mate, will be more applicable to women in the context of dissolved marriages compared with separated cohabitations because the latter are more characterized by a less traditionally slanted role division, with an increasing contribution by men to unpaid work and increasing participation in the labour force by women.

Especially as a context for childbearing, unmarried cohabitation arose only very recently. Whereas in 2000 only $22 \%$ of all children were born into a family with unmarried cohabiting partners in Belgium, this percentage had more than doubled to 46\% in 2013 (ADSEI 2014). Children are an important aspect of family life. Divorced parents are less likely to form a (married or cohabiting) relationship than divorcees without children (Bumpass, Sweet, and Castro-Martin 1990; Chiswick and Lehrer 
1990). However, children have been shown to affect women's and men's likelihood of repartnering somewhat differently (Coleman, Ganong, and Fine 2000; Poortman 2007; Wu and Schimmele 2005; de Graaf and Kalmijn 2003; Ivanova, Kalmijn, and Uunk 2013; Beaujouan 2012; Pasteels and Mortelmans 2015). Research shows that mothers are less likely to repartner than those who are not mothers, with varying effects according to the number and ages of children. Findings as regards men's likelihood of repartnering are more mixed (Coleman, Ganong, and Fine 2000; Poortman 2007; Wu and Schimmele 2005; de Graaf and Kalmijn 2003; Lampard and Peggs 1999; Sweeney 2002). Indicators about parenthood will be included in each model as control variables.

\section{Methods}

In this section we provide more details on the data used in this study, the measurements included in the models, and the analytical strategy.

\subsection{Data}

We use the Data Warehouse Labour Market and Social Protection database. The Data Warehouse is managed by the Crossroads Bank of Social Security (CBSS), which clusters the registry records of social security agencies (see also Mortelmans and Pasteels 2013). ${ }^{3}$ We obtained a random sample for six consecutive years (1999-2004) of people living in Belgium who married or started an unmarried cohabitation in one of these years. Starting an unmarried cohabitation means that partners have transferred their domicile to the same address, regardless of whether or not the cohabitation has been legally recognized. Although legally recognized cohabitation has increased sharply, from 5,144 men or women in 2000 to 79,323 in 2013 (ADSEI 2014), the largest group of unmarried cohabitations is not legally recognized yet. The relationships in the analytical sample were all first marriages or first cohabitations. Both groups had never been married or observed as cohabiting in a previous relationship and married people were never involved in a premarital cohabitation with the marital partner. The sample design does not assume anything about previous relationships that were not visible in the registers (e.g., short cohabitations whereby domiciles have not been transferred to the same address by both partners) and it also gives no information about

\footnotetext{
${ }^{3}$ We would like to thank the Crossroads Bank of Social Security and in particular Mr Brijs for his cooperation in this research.
} 
the actual length of any living-together-apart (LAT) relationship that might have existed before the marriage or cohabitation started.

For the individuals who were initially selected between 1999 and 2004 we obtained additional data for all subsequent years until 2012. So we were able to find out whether - and if so, when - a partnership, either a cohabitation or a marriage, was dissolved or not before 2013. Breaking up is recorded as "leaving the household permanently irrespective of the marital status," meaning that breaking up in marriages does not refer to a legal divorce. Cohabiting people who married were excluded on the event of separation and have not been followed any more for the purposes of this study. Our reasoning for this decision was that the time frame between 1999 or 2004 and 2012 would be too narrow for exploring repartnering dynamics for those who married after some years of cohabitation. The dynamics of relationship dissolution covered by the data from these registers have already been described in previous work (Cooke et al. 2013; Härkönen et al. 2013). Thanks to the richness of the data, we were able to find out whether or not these individuals had repartnered before 2013. Using a selection of divorced or separated individuals as an analytical sample made the data valuable for a study about repartnering. Table 1 gives an overview of the structure and some measures of the original sample from which the analytical sample was taken.

Table 1: Sample descriptors of the original sample

\begin{tabular}{lcccc}
\hline & Married & Cohabiting & \\
\hline N & & 176,112 & 124,140 & $(198,000)$ \\
& 1999 & 35,276 & 27,287 & $(44,000)$ \\
& 2000 & 36,678 & 27,716 & $(44,000)$ \\
2001 & 38,158 & 27,769 & $(44,000)$ \\
2002 & 22,000 & 13,574 & $(22,000)$ \\
2003 & 22,000 & 13,796 & $(22,000)$ \\
$\quad 2004$ & 22,000 & 13,998 & $(22,000)$ \\
\hline Mean age at start of relationship & 29.0 & 28.0 & \\
\% event break-up & $26.5 \%$ & $56.3 \%$ & \\
N event break-up & 46,652 & 69,934 & \\
Mean duration of relationship (if break-up occurs) & 5.6 years & 3.8 years \\
Mean age at break-up & 34.0 & 30.4 & \\
\hline
\end{tabular}

Note: Numbers in parentheses are original sample sizes, including cohabitations that were later transformed into marriages. The latter are left out of the analytical sample for this study.

Source: CBSS, own calculations.

For the analytical subsample, we selected 116,286 individuals who had experienced a break-up and therefore started to have the possibility of repartnering 
(46,652 previously married and 69,934 former cohabiters). The divorcees are somewhat older than the former cohabiters and their relationships lasted longer. Nevertheless, it is clear that both samples are relatively young and not representative of the entire Belgian population. This is because of the restricted time window for observing break-ups. The empirical sample we work with in this study is therefore representative of all break-ups of first direct marriages and cohabitation cohorts from 1999 to 2004.

Figures 1 and 2 show the estimated survival curves and hazard rates of relationship break-up for the original sample. They make it clear that the probability of a break-up is different for marriage and for cohabitation. Significance tests (Logrank, Wilcoxon; both $\mathrm{p}<.001)$ also show that the break-up rate of cohabitation is significantly higher than that of marriage. The mean estimated survival time for married people is 10.90 years, while for cohabiters it is 7.42 years. We find $71.6 \%$ of those married to be excluded and $39.32 \%$ of the cohabiters. The hazard curve shows that the likelihood of break-up is especially high at the start of cohabitation. Afterwards, the curve more or less resembles that of marriage (although at a higher level).

\section{Figure 1: Survival estimates (Kaplan-Meier) of relationship break-up by status (married or cohabiting)}

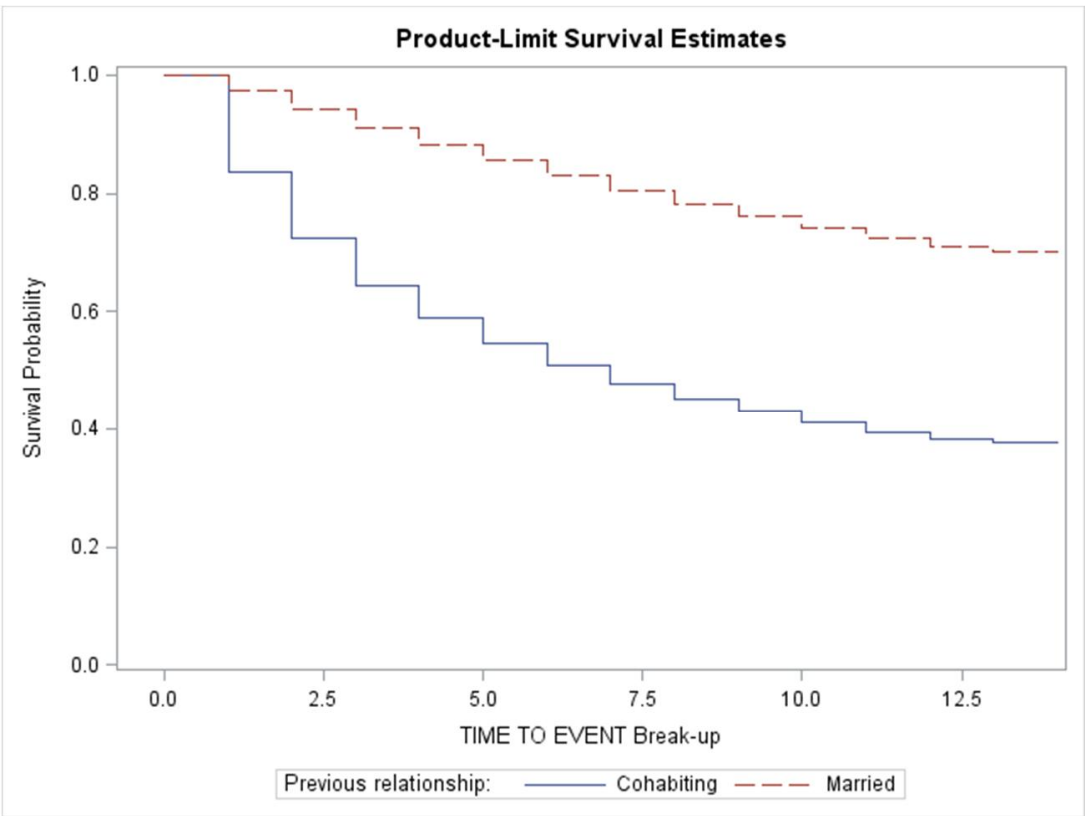


Figure 2: Hazard rates (smoothed) of relationship break-up by status (married or cohabiting)

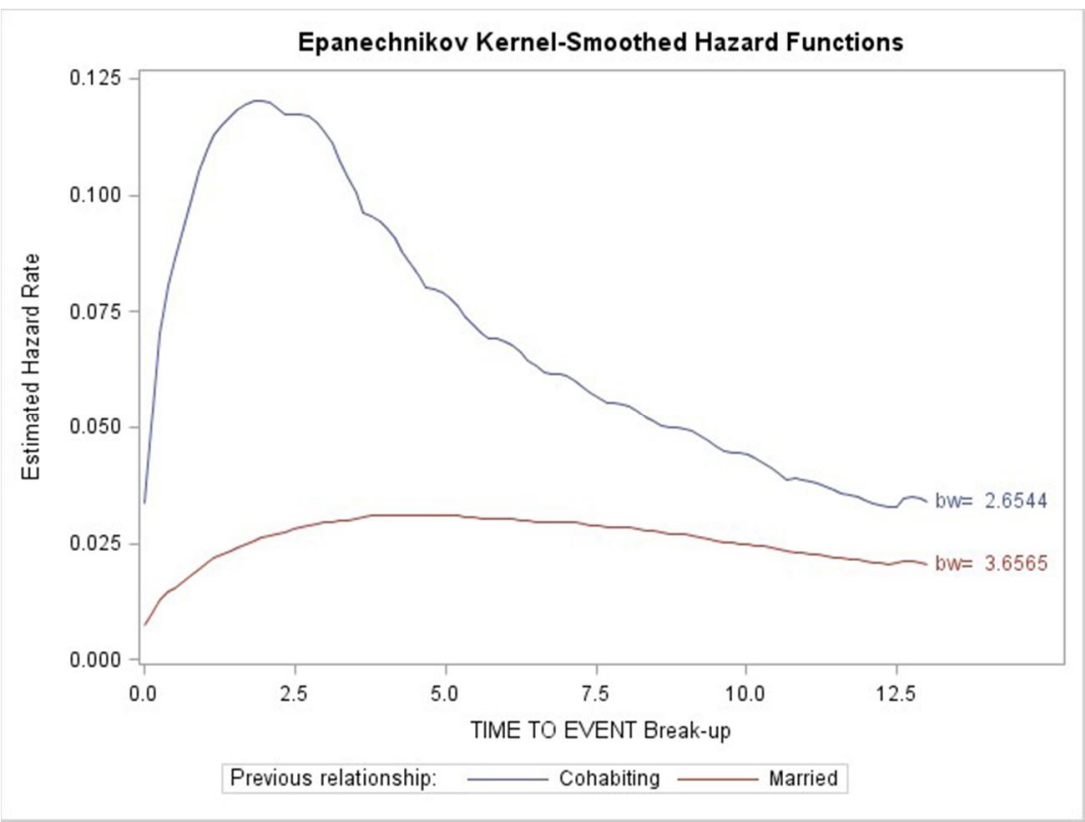

\subsection{Measurements}

The dependent variable is the event of repartnering. First, it should be noted that we have only one demographic position for each year. As with the event of a break-up, the event of repartnering is observed only once each year. We use moving into a household by someone who is not known as a family member and, as far as it is visible in the register, by transfer of domicile as an indicator of repartnering. Romantic relationships that do not lead to the formation of a household where both partners are domiciled at the same address are outside the scope of the study. This is an underestimation of all new partnerships after the break-up of a previous relationship, because LAT relationships and also relationships where people live together without having their domicile at the same address are not considered. Second, we include only those events where the records show the occurrence of a new partner compared with the previous year's data. The recurrence of an original partner is not interpreted as repartnering. Owing to small errors in the records, it is possible that people have missing values in 
some identification variables. This could lead to the erroneous interpretation that the original partner had left the household, which would imply a break-up by our definition (see previous section). If the original partner reappears after one or two years, this may be a reconstitution of the original household, but it may also imply a continuous relationship where some information is missing in the records for a particular year. Since we could not discern the difference between these situations, we decided to exclude them from the risk set. Only the entry of a new partner not present as a partner in the original household is included in the dependent variable. People are excluded if they had not repartnered by 2012 (the end of the observation window). The limitation of having only yearly transitions is present in most register studies but it is also inherent in many panel studies that collect yearly data. However, discrete-time event history models are capable of giving robust estimates even though we have only yearly data.

We use two indicators as income variables. First, we include information about the composition of individual income into the model. For that purpose, we calculate a timevarying dummy that indicates whether or not a particular type of income component, whether from labour, unemployment benefits, or integration income, was received during that year. Unemployment benefits come from Belgian Social Security, while integration income is provided by Belgian Social Assistance (Federal Public Service Social Security 2012).

Second, we include the amount of income by using age- and gender-adjusted income quintiles (time-varying). The lowest income quintile forms the reference category. The quintiles are calculated from the gross individual income (inflation- and OECD-corrected) composed of all gross income from labour and social security or social assistance remittances. The amounts of income from labour and unemployment benefits are available in the CBSS database. ${ }^{4}$ The amounts of integration income and child support are estimated from the data available. Child support is calculated using the number of children in the household, year, ages of children, household composition, and labour market participation of parents and children. Integration income is estimated based on the composition of the household for the person entitled to the integration income. People with only pension benefits are omitted from the analysis because the hypotheses primarily focus on differences between people (partially) participating in the labour market and those with unemployment benefits and integration income.

Age at break-up and gender are individual control variables included in each multivariate model. Furthermore, we include both family-related determinants. Children, and especially children's age, are important elements in the likelihood of individuals repartnering. As not all the individuals in our sample have children, we use a variable combining the presence and the age of the youngest child. We use a fivecategory variable: (1) no children (reference category); (2) one child under the age of

\footnotetext{
${ }^{4}$ Information on partner or child alimony was not present in the registers at the time of the sampling.
} 
three; (3) one child aged three or above; (4) two children or more, of whom the youngest is less than three years of age; (5) two children or more, of whom the youngest is aged three or above. The age of three is used as the cut-off point, as $95 \%$ of all children in Belgium attend kindergarten for at least one year (PISA 2009). Kindergarten is accessible from the age of three, meaning that most children actually start at this age, so the need for childcare decreases then.

\subsection{Analytical strategy}

In the next section we present the descriptive findings on repartnering, after which we turn to the multivariate analyses. We use a discrete-time event history model, with the individuals who have experienced the break-up of a first relationship (either divorce or separation) as the population at risk of repartnering. Because we have yearly data and the number of years is rather limited, we use discrete-time event history analysis. As shown in Figure 4, the functional form of the hazard is not linear. Therefore, we estimate the model using a quadratic duration term. We estimate ten models. For those previously married, for former cohabiters and for both groups combined, we look at the influence of the income determinants, controlled for individual and family characteristics. All models are estimated for men (models a) and women (models b) separately. Because of different childbearing patterns within first-marriage and firstunmarried cohabitation, we control for the number and age of children in all analyses.

\section{Results}

We start this section by presenting some repartnering descriptives. Table 2 gives a descriptive overview of the analytical sample of 113,701 men and women who divorced or separated between 2000 and 2012 and who can then be followed longitudinally in order to study repartnering dynamics. All these divorced or separated individuals are observed until 2012: that is, 13 years (1999) and 8 years (2004) after their first union formation. 
Table 2: Descriptives of at risk of repartnering population by first relationship status

\begin{tabular}{lcc}
\hline & Previously married & Previously cohabiting \\
\hline $\mathrm{N}$ at risk of repartnering ${ }^{*}$ (= break-ups) & 46,648 & 67,053 \\
$\mathrm{~N}$ in person-period file & 201,678 & 327,333 \\
\hline Mean duration to repartnering & 2.24 years & 3.96 years \\
\% events & $51.9 \%$ & $62.8 \%$ \\
& & \\
$\%$ repartnered men & $52.2 \%$ & $61.6 \%$ \\
$\%$ repartnered women & $51.6 \%$ & $64.0 \%$ \\
\hline
\end{tabular}

Note: Differences with $\mathrm{N}$ event break-up in Table 1 are due to lack of information about repartnering status for some individuals. Source: CBSS, own calculations.

Although Figures 3 and 4 show similar survival curves, the repartnering trends differ significantly (Logrank, Wilcoxon; both $\mathrm{p}<.001$ ). Previously married individuals take longer to repartner than former cohabiters. The mean survival time for married people is 5.83 years $(48.10 \%$ excluded), while for cohabiters it is 5.51 years $(37.18 \%$ excluded). This means approximately $10 \%$ more cohabiters find a new partner than those previously married do. The hazard rates (Figure 4) now show a rather similar pattern, with slightly lower hazards for those previously married. However, overall the hazard rate of finding a new partner decreases continuously up to 10 years, where we see a marginal increase.

Next, multivariate models are used to explore repartnering mechanisms in the sample of divorcees and former cohabiters. First, we look separately at previously married people (Models 1a and 1b) and former cohabiters (Models 2a and 2b). In the next two models ( $3 a$ and $3 b$ ) we include all individuals, but control for the previous relationship status. In Models $4 \mathrm{a}$ and $4 \mathrm{~b}$ we consider an interaction effect between type of relationship and amount of income. Finally, we add an interaction effect between type of relationship and source of income in Models 5a and 5b. 
Figure 3: $\quad$ Survival estimates (Kaplan-Meier) of repartnering by previous relationship status (married or cohabiting)

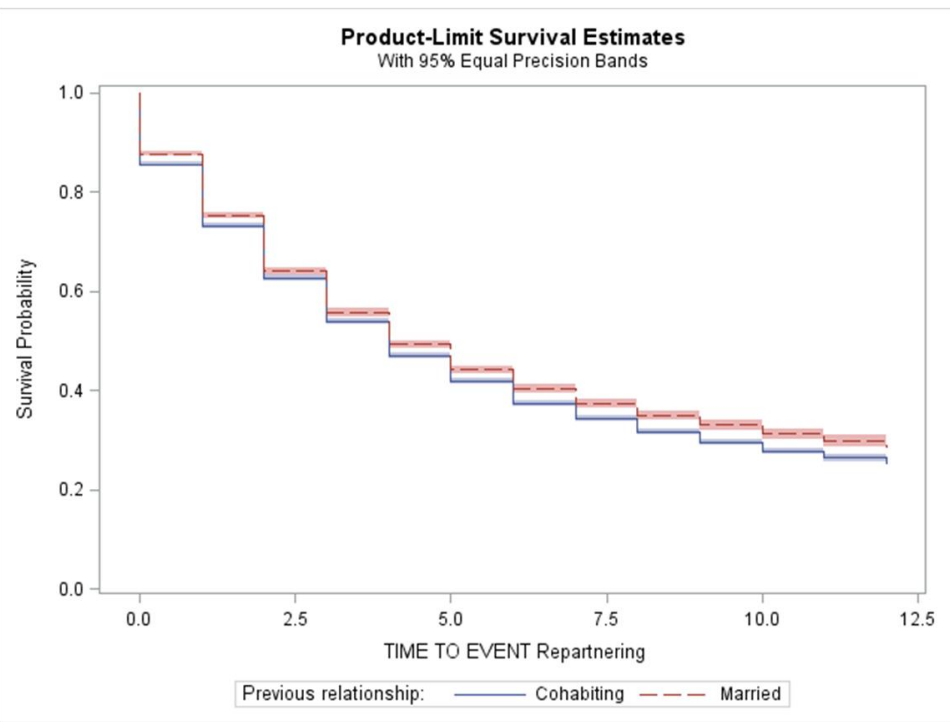

Figure 4: Hazard rates (smoothed) of repartnering by previous relationship status (married or cohabiting)

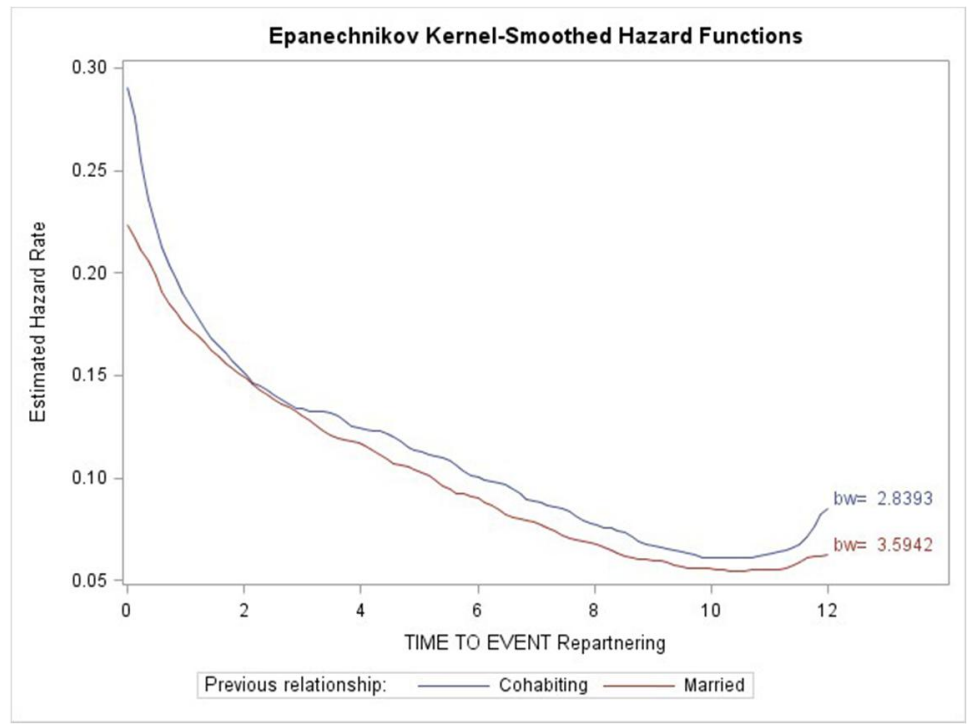


First, Models 1 and 2 show that the amount of income plays a diverse and genderspecific role. Men in the highest income quintiles have the strongest repartnering likelihood, while the opposite effect is found for women. Women in the lower income quintiles have higher repartnering chances, while women in the highest income quintiles are less likely to repartner. This pattern is found for previously married people as well as for previously cohabiting ones. Source of income also has an important impact on repartnering dynamics. Men and women in the labour force have a higher repartnering likelihood, even if their work is only part-time and supplemented by unemployment benefits. On the contrary, men and women who have no income from labour and get only unemployment benefits and/or an integration income are less likely to repartner. The effects hold for divorced as well as for separated people and seem to be stronger for women than for men in both samples.

Models 3, 4, and 5 are combined models, meaning that the samples of divorced people and of cohabiting people are taken together in order to explore the impact of relationship status on repartnering dynamics. In these models the effects of amount of income and source of income respectively still hold, meaning that the same patterns are found compared to the effects found in Models 1 and 2. In addition, Model 3 shows that married people are more likely to repartner than separated people are and this effect tends to be larger for women than for men.

Model 4 includes an interaction effect between amount of income and type of previous relationship, but hardly any effect could be found. Only for men belonging to the lower income quintile did the repartnering likelihood significantly increase compared to the lowest income quintile if they had been married rather than previously cohabiting. For women, no interaction effect between amount of income and type of previous relationship could be found.

Interaction effects between source of income and type of previous relationship are included in Models 5a and 5b. For both men and women, repartnering chances decreased in years with unstable labour market participation if they had been married before. Furthermore, the likelihood of repartnering given a wage from labour increases if women are divorced, while no effect could be found for men. On the contrary, for men with unemployment benefits and/or integration income, their repartnering chances increase after divorce compared to separation. 
Pasteels \& Mortelmans: The socioeconomic determinants of repartnering after divorce or separation

Table 3: Discrete-time event history analysis (exp(estimates) and sign test) of repartnering for previously married and cohabitating

\begin{tabular}{|c|c|c|c|c|c|c|}
\hline Model & 1a & $1 b$ & $2 a$ & $2 b$ & 3a & $3 b$ \\
\hline & \multicolumn{2}{|c|}{ Previously married } & \multicolumn{2}{|c|}{ Previously cohabiting } & \multicolumn{2}{|c|}{ Both } \\
\hline & Men & Women & Men & Women & Men & Women \\
\hline Duration & $1.081^{\star \star \star}$ & $1.027^{*}$ & $0.942^{\star \star \star}$ & 0.984 & $0.985^{\star}$ & 0.998 \\
\hline Duration ${ }^{2}$ & $0.984^{\star \star \star}$ & $0.986^{\star \star \star}$ & $0.998^{*}$ & $0.992^{\star \star \star}$ & $0.994^{\star \star \star}$ & $0.990^{* \star *}$ \\
\hline Previous relationship (ref $=$ cohabiting) & & & & & $1.056^{\star \star *}$ & $1.113^{\star * *}$ \\
\hline Age at break-up & $0.935^{\star \star \star}$ & $0.948^{* * *}$ & $0.942^{* \star *}$ & $0.942^{* * *}$ & $0.940^{* * *}$ & $0.945^{* * *}$ \\
\hline \multicolumn{7}{|l|}{ Children (ref = no children) } \\
\hline 1 child under 3 years old & $1.579^{\star \star \star}$ & $0.730^{\star \star \star}$ & $1.355^{\star \star \star}$ & $0.766^{\star * *}$ & $1.433^{\star \star \star}$ & $0.755^{\star \star *}$ \\
\hline 1 child above 3 years old & $2.743^{\star * *}$ & $0.397^{* * *}$ & $3.166^{\star \star \star}$ & $0.482^{* * *}$ & $2.921^{\star * *}$ & $0.437^{* * *}$ \\
\hline $2+$ children, youngest $<3$ years old & $2.221^{* \star *}$ & $0.734^{* * *}$ & 1.021 & $0.430^{* \star *}$ & $1.343^{* \star *}$ & $0.553^{\star \star *}$ \\
\hline $2+$ children, youngest $>3$ years old & $2.983^{\star \star \star}$ & $0.428^{* * *}$ & $5.002^{* \star *}$ & $0.564^{\star \star \star}$ & $3.566^{\star \star \star}$ & $0.469^{* \star *}$ \\
\hline \multicolumn{7}{|l|}{ Amount of income (ref = Quintile 1 ) } \\
\hline Quintile 2 & 0.999 & $1.065^{\star * *}$ & $0.968^{*}$ & $1.065^{\star \star *}$ & 0.979 & $1.066^{* * *}$ \\
\hline Quintile 3 & 0.990 & 1.001 & 1.013 & 1.009 & 1.003 & 1.005 \\
\hline Quintile 4 & $1.058^{*}$ & 0.970 & $1.125^{\star \star *}$ & $0.958^{*}$ & $1.095^{\star \star \star}$ & $0.960^{* * *}$ \\
\hline Quintile 5 & $1.106^{\star * *}$ & $0.908^{* \star *}$ & $1.181^{\star \star \star}$ & $0.926^{\star * *}$ & $1.151^{\star \star \star}$ & $0.917^{\star \star \star}$ \\
\hline Income from labour (ref = no income) & $1.273^{\star \star \star}$ & $1.532^{\star \star \star}$ & $1.213^{\star \star \star}$ & $1.597^{\star \star \star}$ & $1.242^{\star \star \star}$ & $1.580^{* \star *}$ \\
\hline $\begin{array}{l}\text { Income from unstable labour (ref = no } \\
\text { income) }\end{array}$ & $1.177^{\star \star \star}$ & $1.365^{\star \star \star}$ & $1.135^{\star \star \star}$ & $1.185^{\star \star \star}$ & $1.153^{\star \star \star}$ & $1.247^{* \star \star}$ \\
\hline $\begin{array}{l}\text { Unemployment benefits or integration } \\
\text { income (ref = no income) }\end{array}$ & $0.728^{\star \star \star}$ & $0.748^{* \star *}$ & $0.717^{\star \star *}$ & $0.753^{* * *}$ & $0.720^{\star \star \star}$ & $0.756^{* * *}$ \\
\hline \multicolumn{7}{|l|}{$\begin{array}{l}\text { Amount of income (ref = Quintile } 1)^{\star} \\
\text { previous relationship (ref = cohabiting) }\end{array}$} \\
\hline \multicolumn{7}{|l|}{ Quintile $2^{*}$ prev. married } \\
\hline \multicolumn{7}{|l|}{ Quintile $3^{*}$ prev. married } \\
\hline \multicolumn{7}{|l|}{ Quintile $4^{*}$ prev. married } \\
\hline \multicolumn{7}{|l|}{ Quintile $5^{\star}$ prev. married } \\
\hline \multicolumn{7}{|l|}{$\begin{array}{l}\text { Type of income }(\text { ref }=\text { Quintile } 1)^{\star} \\
\text { previous relationship (ref }=\text { cohabiting) }\end{array}$} \\
\hline \multicolumn{7}{|l|}{ Labour* prev. married } \\
\hline \multicolumn{7}{|l|}{ Unstable labour ${ }^{\star}$ prev. married } \\
\hline \multicolumn{7}{|l|}{$\begin{array}{l}\text { Unemployment benefits or integration } \\
\text { Income* prev. married }\end{array}$} \\
\hline AIC & $70,606.900$ & $68,722.796$ & $120,511.20$ & $115,058.21$ & $191,517.28$ & $183,979.86$ \\
\hline Person periods (events) & 12,017 & 11,862 & 20,342 & 20,428 & 32,359 & 32,300 \\
\hline
\end{tabular}


Table 3: (Continued)

\begin{tabular}{|c|c|c|c|c|}
\hline Model & $4 a$ & $4 b$ & $5 a$ & $5 b$ \\
\hline & \multicolumn{2}{|c|}{ Both } & \multicolumn{2}{|c|}{ Both } \\
\hline & Men & Women & Men & Women \\
\hline Duration & $0.985^{*}$ & 0.998 & 0.986 & 0.999 \\
\hline Duration $^{2}$ & $0.994^{\star \star \star}$ & $0.990^{* * *}$ & $0.994^{\star \star \star}$ & $0.990^{* * *}$ \\
\hline Previous relationship ( ref = cohabiting) & $1.048^{\star * *}$ & $1.111^{* * *}$ & $1.083^{\star \star \star}$ & $1.132^{* * *}$ \\
\hline Age at break-up & $0.940^{\star \star \star}$ & $0.945^{\star \star *}$ & $0.940^{\star \star \star}$ & $0.945^{\star \star *}$ \\
\hline \multicolumn{5}{|l|}{ Children (ref = no children) } \\
\hline 1 child under 3 years old & $1.432^{\star \star \star}$ & $0.756^{* \star *}$ & $1.434^{\star \star \star}$ & $0.757^{* * *}$ \\
\hline 1 child above 3 years old & $2.924^{\star \star \star}$ & $0.438^{* * *}$ & $2.920^{\star \star \star}$ & $0.437^{\star * *}$ \\
\hline $2+$ children, youngest $<3$ years old & $1.343^{* \star *}$ & $0.553^{* * *}$ & $1.344^{* \star *}$ & $0.553^{* * *}$ \\
\hline $2+$ children, youngest $>3$ years old & $3.578^{\star \star \star}$ & $0.469^{\star \star \star}$ & $3.570^{\star \star \star}$ & $0.469^{* * *}$ \\
\hline \multicolumn{5}{|l|}{ Amount of income (ref = Quintile 1) } \\
\hline Quintile 2 & 0.987 & $1.070^{* * *}$ & 0.980 & $1.066^{* * *}$ \\
\hline Quintile 3 & 1.004 & 1.004 & 1.004 & 1.005 \\
\hline Quintile 4 & $1.089^{\star * *}$ & $0.960^{\star \star *}$ & $1.095^{\star \star \star}$ & $0.960^{* * *}$ \\
\hline Quintile 5 & $1.142^{\star \star \star}$ & $0.912^{\star \star *}$ & $1.150^{\star \star \star}$ & $0.916^{* * *}$ \\
\hline Income from labour (ref = no income) & $1.241^{\star \star *}$ & $1.580^{\star \star *}$ & $1.161^{\star \star \star}$ & $1.272^{\star \star *}$ \\
\hline Income from unstable labour (ref = no income) & $1.154^{\star \star *}$ & $1.248^{* * *}$ & $1.226^{* \star *}$ & $1.565^{\star * *}$ \\
\hline $\begin{array}{l}\text { Unemployment benefits or integration income } \\
\text { (ref = no income) }\end{array}$ & $0.721^{\star \star *}$ & $0.756^{\star \star *}$ & $0.735^{\star \star \star}$ & $0.755^{\star \star *}$ \\
\hline \multicolumn{5}{|l|}{$\begin{array}{l}\text { Amount of income }(\text { ref }=\text { Quintile } 1)^{\star} \text { previous } \\
\text { relationship (ref }=\text { cohabiting) }\end{array}$} \\
\hline Quintile $2^{*}$ prev. married & $1.028^{*}$ & 1.014 & & \\
\hline Quintile 3* prev. married & 1.000 & 0.996 & & \\
\hline Quintile $4^{*}$ prev. married & 0.978 & 0.999 & & \\
\hline Quintile $5^{*}$ prev. married & 0.975 & 0.982 & & \\
\hline \multicolumn{5}{|l|}{$\begin{array}{l}\text { Type of income (ref = Quintile } 1)^{\star} \\
\text { previous relationship (ref = cohabiting) }\end{array}$} \\
\hline Labour* prev. married & & & 1.024 & $1.068^{* \star *}$ \\
\hline Unstable labour ${ }^{\star}$ prev. married & & & $0.960^{\star \star \star}$ & $0.968^{\star * *}$ \\
\hline $\begin{array}{l}\text { Unemployment benefits or integration } \\
\text { income* prev. married }\end{array}$ & & & $1.068^{\star \star \star}$ & 1.011 \\
\hline AIC & $191,515.40$ & $183,984.65$ & $191,493.90$ & $183,956.40$ \\
\hline Person periods (events) & 32,359 & 32,300 & 32,359 & 32,300 \\
\hline
\end{tabular}




\section{Discussion}

The main goal of this study is to explore the influence of income characteristics on the repartnering mechanisms of divorcees and former cohabiters. For that purpose, discretetime event history models with income and previous relationship status are estimated.

First, we examine amount of income and source of income, taking these two components of income as socioeconomic indicators. Referring to the amount of income, we find that the likelihood of men repartnering increases for higher quintiles regardless of the type of previous relationship and decreases for male former cohabiters belonging to the second income quintile. Women from the second income quintile are more likely to repartner, while for the highest quintiles women's likelihood of repartnering decreases. These results hold for female divorcees as well as for female former cohabiters. With respect to the first two hypotheses, these findings clearly show that the effect of the amount of income on repartnering dynamics is gender-influenced. For men, lower incomes do not increase repartnering chances, so the economic-needs hypothesis has to be rejected. On the contrary, for male former cohabiters from the second income quintile, the attractiveness hypothesis holds, meaning that their repartnering likelihood is decreased. Attractiveness also seems to be important for men's repartnering in a second way: that is, that greater earnings are a desirable characteristic for a man as a potential partner. Simultaneously, the economic-needs hypothesis is confirmed in both ways for women: if they belong to the lower categories of income compared to the lowest, their need to repartner is more pronounced than their unattractiveness as a financially poor new partner. Moreover, if women belong to the higher income groups their decreased economic need to repartner is more pronounced than their attractiveness as a potential economically strong partner.

The components of the income are also significant, with income from labour being the main driver to having a new partner. Gaining income from work is equally important regardless of gender: both men and women profit from the networks that labour gives them. Referring to the type of income, the likelihood of repartnering for male and female divorcees as well as for male and female former cohabiters is increased if income can be gained from labour. These findings still hold even if controlled for the amount of income. This strongly suggests that the third hypothesis has to be confirmed, meaning that labour market participation offers the opportunity to meet potential candidates for repartnering for women as well as for men. This is completely in line with previous empirical evidence (Hughes 2000; de Graaf and Kalmijn 2003).

Second, we explore the impact of type of previous relationship on repartnering dynamics. Here, in contrast to existing literature (Poortman 2007; Wu and Schimmele 2005; Skew, Evans, and Gray 2009), results show that divorcees are more likely to 
repartner than former cohabiters are and these results are robust even when interaction effects are added. So we conclude that the fourth hypothesis has to be rejected.

Third, the interaction effects added to the combined model of divorcees and former cohabiters give some crucial information about hypotheses $\mathrm{v}$ and vi. We hypothesized that the economic-needs theory would be less applicable to women in the context of dissolved marriages compared with separated cohabitations because the legal context of divorce provides the opportunity to obtain alimony from the ex-husband if an ex-wife is the economically weaker party. Results show no significant effect for women on the interaction between amount of income and type of relationship, so we have to reject the idea that women's economic need is influenced by previous relationship status and the subsequent legal context. Surprisingly, for men belonging to the second income quintile we found a positive effect regarding their repartnering chances if they were previously married. Divorce after marriage seems to create economic needs for men belonging to the lower income groups.

Finally, the models with an interaction effect between the source of income and relationship type shed light on the last hypothesis (vi): "Opportunity theory, which states that participating in the labour force provides opportunities to meet and mate, will be more applicable to women in the context of dissolved marriages compared with separated cohabitations because the latter are more characterized by a less traditionally slanted role division, with an increasing contribution by men to unpaid work and increasing participation in the labour force by women." The results clearly show that the hypothesis cannot be rejected. For women, the effect of being married instead of cohabiting magnifies the main impact of source of income on repartnering dynamics in the case of wages from regular labour. If women participate only partially in the labour market, the likelihood of repartnering decreases for divorcees compared to former cohabiters. For men, the same result is found for unstable labour as source of income; surprisingly, though, if they got unemployment benefits or an integration income their likelihood of repartnering increased after divorce compared to separation.

Overall, socioeconomic indicators seem to be influential factors in a person's likelihood of repartnering. Moreover, we conclude that the repartnering "market" is evolving into a two-tier system. This concept of a two-tier family system refers to Frank Furstenberg's theory that describes a discrepancy between lower and higher income groups with regard to family behaviour (Furstenberg 2016). In this study, we find that repartnering is substantially different between the lowest and highest income groups and between people who are involved in the labour market and those who are not. In addition, we find that the effect of the amount of income on repartnering is strongly driven by gender-specific patterns, but also that the type of previous relationship matters. Concerning the amount of income, the effects were found to be largely equivalent for both types of relationships under consideration, but the impact of source 
of income on repartnering had interaction effects. So we conclude that the type of previous relationship has significance in clarifying the impact of income on repartnering dynamics if amount and composition are considered as two separate components.

In this research, we combine registry-based time-varying information about the amount and composition of income with previous relationship status in order to explain men's and women's likelihood of repartnering. The sociology of the life course stresses temporal shifts in people's lives. Cross-sectional or retrospective data is often all that is available, forcing us to use one-time "snapshots" of families. The major advantage of the registry information is that we can observe the repartnering of divorced and separated people over time. It allows us to see which relationship trajectories lead to a new partner and how income trajectories play a role in this process. The strength of this analysis is the use of time-varying information about the amount and composition of income.

However, the study also has certain limitations. First, we use moving into a household by someone who is not known as a family member as the indicator for repartnering. This means that we may underestimate the phenomenon of repartnering, as some divorcees or former cohabiters, especially mothers, may choose a LAT relationship, in which the partner does not live permanently in the household (Pasteels and Mortelmans 2015). In addition, in some cases people start cohabitation without transferring their domicile. If so, we do not consider these individuals as being repartnered because we use a common address in the data source as our indicator for repartnering. Second, we draw a subsample from a sample of previously married or cohabiting people. The mechanisms of divorce or separation preceded the selection of the subsample we use and are therefore not included in the analysis of repartnering. Further research could focus on two-stage models in order to explore simultaneously the socioeconomic differentials of divorce or separation and repartnering dynamics of divorcees compared with those of former cohabiters. It might explore if the two-tier gendered partner market in younger generations is mirrored in the mechanisms that lead to the break-up in the first place.

\section{Acknowledgements}

The research leading to these results has received funding from the European Union's Seventh Framework Programme (FP7/2007-2013) under grant agreement no. 320116 for the research project FamiliesAndSocieties. 


\section{References}

ADSEI (2014). Algemene Directie Statistiek en Economische Informatie-Thematische Directie Samenleving, Bevolkingscijfers [electronic resource]. Brussels: Statistics Belgium. http://statbel.fgov.be/nl/statistieken/cijfers/bevolking

Amato, P., Booth, A., Johnson, D., and Stacy, J. (2007). Alone together: How marriage in America is changing. Cambridge: Harvard University Press.

Amato, P. (2010). Research on divorce: Continuing trends and new developments. Journal of Marriage and Family 72(3): 650-666. doi:10.1111/j.1741-3737.2010. 00723.x.

Beaujouan, E. (2012). Repartnering in France: The role of gender, age and past fertility. Advances in Life Course Research 17(2): 69-80. doi:10.1016/j.alcr.2012.03.001.

Becker, G. (1981). A treatise on the family. Cambridge: Harvard University Press.

Billari, F.C. (2001). The analysis of early life courses: Complex descriptions of the transition to adulthood. Journal of Population Research 18(2): 119-142. doi:10.1007/BF03031885.

Blossfeld, H.-P. and Drobnic, S. (2001). Careers of couples in contemporary society form male breadwinner to dual-earner families. Oxford: Oxford University Press.

Bumpass, L., Sweet, J., and Castro-Martin, T. (1990). Changing patterns of remarriage. Journal of Marriage and Family 52(3): 747-756. doi:10.2307/352939.

Cherlin, A. (2004a). The marriage-go-around: The state of marriage and family in America today. New York: Knopf.

Cherlin, A. (2004b). The deinstitutionalization of American marriage. Journal of Marriage and Family 66(4): 848-861. doi:10.1111/j.0022-2445.2004. 00058.x.

Chiswick, C. and Lehrer, E. (1990). On marriage-specific capital: Its role as a determinant of remarriage. Journal of Population Economics 3(3): 193-213. doi:10.1007/BF00163075.

Coleman, M., Ganong, L., and Fine, M. (2000). Reinvestigating remarriage: Another decade of progress. Journal of Marriage and Family 62(4): 1288-1307. doi:10.1111/j.1741-3737.2000.01288.x. 
Cooke, L.P., Erola, J., Evertsson, M., Gahler, M., Härkönen, J., Hewitt, B., Jalovaara, M., Kan, M., Lyngstad, T.H., Mencarini, L., Mignot, J.-F., Mortelmans, D., Poortman, A.-R., Schmitt, C., and Trappe, H. (2013). Labor and love: Wives' employment and divorce risk in its socio-political context. Social Politics: International Studies in Gender, State and Society 20(4): 482-509. doi:10.1093/ $\mathrm{sp} / \mathrm{jxt} 016$.

De Graaf, P. and Kalmijn, M. (2003). Alternative routes in the marriage market: Competing-risk analyses of union formation after divorce. Social Forces 81(4): 1459-1498. doi:10.1353/sof.2003.0052.

Dewilde, C. and Uunk, W. (2008). Remarriage as a way to overcome the financial consequences of divorce: A test of the economic need hypothesis for European women. European Sociological Review 24(3): 393-407. doi:10.1093/esr/jen025.

Dykstra, A.P. and Poortman, A.-R. (2009). Economic resources and remaining single: Trends over time. European Sociological Review 26(3): 277-290. doi:10.1093/ esr/jcp021.

Easterlin, R. (1978). What will 1984 be like? Socioeconomic implications of recent twists in age structure. Demography 15(4): 397-432. doi:10.2307/2061197.

Elder, G.H.J., Johnson, M.K., and Crosnoe, R. (2003). The emergence and development of life course theory. In: Mortimer, J.T. and Shanahan, M.J. (eds.). Handbook of the life course. New York: Springer: 3-19. doi:10.1007/978-0-306-48247-2_1.

Elder, G.H.J. (1998). The life course as developmental theory. Child Development 69(1): 1-12. doi:10.1111/j.1467-8624.1998.tb06128.x.

Federal Public Service Social Security (2012). Social security: Everything you have always wanted to know. Brussels: FPS Social Security.

Furstenberg, F. (2016). The changing American family: An overview from 1965 to 2015. In: Mortelmans, D., Matthijs, K., Alofs, K., and Segaert, B. (eds.). Changing family dynamics and demographic evolution: The family kaleidoscope. Cheltenham: Edward Elgar: 13-25.

Härkönen, J., Jalovaara, M., Mortelmans, D., and Pasteels, I. (2013). Divorce risks of married and cohabiting couples. A register based study from Belgium, Finland and Sweden. Annual meeting of the European Network for the sociological and demographic Study of Divorce, Oxford. 
Hiekel, N., Liefbroer, A., and Poortman, A.-R. (2012). The meaning of cohabitation across Europe. Paper presented at the European Population Conference (EPC), Stockholm, Sweden, June 13-16, 2012.

Heuveline, P. and Timberlake, J. (2004). The role of cohabitation in family formation: The United States in comparative perspective. Journal of Marriage and Family 66(5): 1214-1230. doi:10.1111/j.0022-2445.2004.00088.x.

Hughes, J. (2000). Repartnering after divorce: Marginal mates and unwedded women. Family Matters 55: 16-21.

Ivanova, K., Kalmijn, M., and Uunk, W. (2013). The effect of children on men's and women's chances of re-partnering in a European context. European Journal of Population 29(4): 417-444. doi:10.1007/s10680-013-9294-5.

Jansen, M., Mortelmans, D., and Snoeckx, L. (2009). Repartnering and (re)employment: Strategies to cope with the economic consequences of partnership dissolution. Journal of Marriage and Family 71(5): 1271-1293. doi:10.1111/j.1741-3737.2009.00668.x.

Jarvis, S. and Jenkins, S. (1999). Marital splits and income changes: Evidence from the British Household Panel Survey. Population Studies 53(2): 237-254. doi: $10.1080 / 00324720308077$.

Kiernan, K. (2004). Unmarried cohabitation and parenthood in Britain and Europe. Law \& Policy 26(1): 33-55. doi:10.1111/j.0265-8240.2004.00162.x.

Lampard, R. and Peggs, K. (1999). Repartnering: The relevance of parenthood and gender to cohabitation and remarriage among the formerly married. British Journal of Sociology 50(3): 443-465. doi:10.1111/j.1468-4446.1999.00443.x.

Lyssens-Danneboom, V., Eggermont, S., and Mortelmans, D. (2013). Living apart together (LAT) and law: Exploring legal expectations among LAT individuals in Belgium. Social \& Legal Studies 22(3): 357-376. doi:10.1177/ 0964663913478960.

Manning, W. (1993). Marriage and cohabitation following premarital conception. Journal of Marriage and Family 55(4): 839-850. doi:10.2307/352766.

Mortelmans, D. and Pasteels, I. (2013). Using register data in the social sciences. SAGE Cases in Methodology.

Mott, F. and Moore, S. (1983). The tempo of remarriage among young American women. Journal of Marriage and Family 45(2): 427-436. doi:10.2307/ 351521. 
Oppenheimer, V. (1988). A theory of marriage timing: Assortative mating under various degrees of uncertainty. American Journal of Sociology 94(3): 563-591. doi:10.1086/229030.

Ozawa, M. and Yoon, H.-S. (2002). The economic benefit of remarriage: Gender and income class. Journal of Divorce and Remarriage 36(3-4): 21-39. doi:10.1300/J087v36n03_02.

Pasteels, I. and Mortelmans, D. (2015). Dyadic analysis of repartnering after divorce: Do children matter? Journal of Family Research 10: 143-164.

Pasteels, I., Lodewijckx, E., and Mortelmans, D. (2015). Wonen in Vlaanderen... Voor elk gezin wat wils? In: Luyten, D., Emmery, K., Pasteels, I., and Geldof, D. (eds.). De sleutel past niet meer op elke deur. Dynamische gezinnen en flexible wonen. Antwerp: Garant: 39-78.

Pasteels, I. and Mortelmans, D. (2013). Gescheiden en dan? Herpartneren in Vlaanderen. Relaties en Nieuwe Gezinnen 3(3): 1-66.

Pasteels, I., Corijn, M., and Mortelmans, D. (2012). Voorhuwelijks samenwonen: Een vergelijking tussen intacte en niet-intacte huwelijken in Vlaanderen. Relaties en Nieuwe Gezinnen 2(4): 1-25.

Perelli-Harris, B., Sigle-Rushton, W., Lappegard, T., Jasilioniene, A., Di Giulio, P., Keizer, R., and Kreyenfeld, M. (2009). Examining nonmarital childbearing in Europe: How does union context differ across countries. Rostock: Max Planck Institute for Demographic Research (MPIDR working paper WP-2009-021).

PISA (2009). Heeft participatie aan kleuteronderwijs een invloed op de leesvaardigheid van 15-jarigen? Gent: Universiteit Gent.

Poortman, A-R. (2000). Sex differences in the economic consequences of separation: A panel study of the Netherlands. European Sociological Review 16(4): 367-383. doi:10.1093/esr/16.4.367.

Poortman, A.-R. (2007). The first cut is the deepest? The role of the relationship career for union formation. European Sociological Review 23(5): 585-598. doi:10.1093/esr/jem024.

Raley, R.K. (2001). Increasing fertility in cohabiting unions: Evidence for the second demographic transition in the United States? Demography 38(1): 59-66. doi:10.1353/dem.2001.0008. 
Rindfuss, R. and van den Heuvel, A. (1990). Cohabitation: A precursor to marriage or an alternative to being single? Population and Development Review 16(4): 703726. doi: $10.2307 / 1972963$.

Seltzer, J.A. (2004). Cohabitation in the United States and Britain: Demography, kinship and the future. Journal of Marriage and Family 66(4): 921-928. doi:10.1111/j.0022-2445.2004.00062.x.

Schmiege, C., Richards, L., and Zvonkovic, A. (2001). Remarriage: For love or money? Journal of Divorce and Remarriage 36(1-2): 123-140. doi:10.1300/ J087v36n01_07.

Skew, A., Evans, A., and Gray, E. (2009). Repartnering in the United Kingdom and Australia. Journal of Comparative Family Studies 40(4): 563-585.

Shafer, K. and Spencer, L. (2013). Gender and socioeconomic status differences in first and second marriage formation. Journal of Marriage and Family 75(3): 544564. doi:10.1111/jomf.12024.

Smock, P. (1994). Gender and the short run economic consequences of marital disruption. Social Forces 73(1): 243-262. doi:10.2307/2579925.

Smock, P. (2000). Cohabitation in the United States: An appraisal of research themes, findings and implications. Annual Review of Sociology 26: 1-20. doi:10.1146/ annurev.soc.26.1.1.

Sobotka, T. and Toulemon, L. (2008). Changing family and partnership behaviour: Common trends and persistent diversity across Europe. Demographic Research 19(6): 85-138. doi:10.4054/DemRes.2008.19.6.

Sweeney, M. (1997). Remarriage of men and women after divorce: The role of socioeconomic prospects. Journal of Family Issues 18(5): 479-502. doi:10.1177/ 019251397018005002.

Sweeney, M. (2002). Two decades of family change: The shifting economic foundations of marriage. American Sociological Review 67(1): 132-147. doi: $10.2307 / 3088937$.

Vanassche, S., Corijn, M., and Matthijs, K. (2015). Post-divorce family trajectories of men and women in Flanders. Demographic Research 32(31): 859-872. doi:10.4054/DemRes.2015.32.31.

$\mathrm{Wu}, \mathrm{Z}$. and Schimmele, C. (2005). Repartnering after first union disruption. Journal of Marriage and Family 67(1): 27-36. doi:10.1111/j.0022-2445.2005.00003.x. 
Pasteels \& Mortelmans: The socioeconomic determinants of repartnering after divorce or separation

Zwaan, T. (1993). De verbroken viereenheid: Een interpretatie van recente transities. In: Zwaan, T. (ed.). Familie, huwelijk en gezin in West-Europa. Amsterdam: Boom: 265-296. 